\title{
Development of a Combined Flotation and High Pressure Leaching Process for Copper and Nickel Recovery from Mine Tailing
}

\author{
Refilwe Sandra Magwaneng1, Altansukh Batnasan', Kazutoshi Haga², Atsushi Shibayama1 \\ ${ }^{1}$ Graduate School of International Resource Sciences, Akita University, Akita, Japan \\ ${ }^{2}$ Graduate School of Engineering Sciences, Akita University, Akita, Japan \\ Email: fyfymags@gmail.com
}

How to cite this paper: Magwaneng, R.S., Batnasan, A., Haga, K. and Shibayama, A. (2017) Development of a Combined Flotation and High Pressure Leaching Process for Copper and Nickel Recovery from Mine Tailing. Journal of Minerals and Materials Characterization and Engineering, 5, 118131.

https://doi.org/10.4236/jmmce.2017.53010

Received: March 1, 2017

Accepted: May 23, 2017

Published: May 26, 2017

Copyright $\odot 2017$ by authors and Scientific Research Publishing Inc. This work is licensed under the Creative Commons Attribution International License (CC BY 4.0).

http://creativecommons.org/licenses/by/4.0/

\section{(c) (i) Open Access}

\begin{abstract}
The present study focused on the re-processing of copper and nickel from mine tailings. In this work, recovery of copper and nickel from mine tailing by combined process of flotation and high pressure oxidative leaching were considered. In the first stage, effects of flotation parameters including collector type, collector dosage, and $\mathrm{pH}$ and pulp density were examined. The results showed that over $80 \%$ copper recovery was achieved under the optimized flotation conditions while nickel recovery was lower than $30 \%$ due to its co-existence with gangue minerals of pyrrhotite, pyrite and other clay minerals. In the second stage, key parameters, particularly concentration of sulfuric acid, temperature, pressure and leaching time were investigated to test the leaching efficiency of copper and nickel from the flotation concentrate with high pressure oxidative leaching (HPOL). A comparison was made between the leaching efficiencies of copper and nickel from flotation concentrates and mine tailing.
\end{abstract}

\section{Keywords}

Mine Tailing, Flotation, High Pressure Leaching, Copper, Nickel

\section{Introduction}

Flotation is of interesting topic in recycling ions by using surficial reactors. Its efficiency is dependent on the hydrophobic and hydrophilic properties of mineral sample [1] [2] [3]. Improving recovery of minerals by studying their relationship between different parameters of flotation and floatability has been a long-standing goal within the mineral processing industry. However, some of the minerals are not fully recovered during this process and end up reporting to the ever increasing mine tailings that occupy a wide area in many mining coun- 
tries. This increase in tailings presents an environmental problems in many regions [3]. In the case that the mine tailings are exposed to weathering, chemical percolation, some heavy metals become more soluble and mobile [4] [5] [6]. The metals that had been leached into the ground act as sources of contamination, which extends to the underground water reserves and soil. In order to address these problems, many researches have been made, aiming at metal recovery through improving separation methods, such as flotation, pyrometallurgy and hydrometallurgy [5] [7] [8] [9]. Despite that, it is difficult to achieve a comprehensive recovery. Minerals in the flotation concentrates from mine tailing have to be further processed by leaching. High pressure leaching presents a better option as it is operationally economic. In the leaching process, metals from the flotation concentrates are enriched into a pregnant leached solution with aid of acid reagent. It is therefore important that mineral interactions at flotation and leaching are quantified to understand effective recoveries of minerals and ways of rejecting iron gangue minerals [10] [11] [12] [13]. As a typical base metal mine in Botswana, BCL Limited mine has been storing its tailing from flotation since commencement in 1973 [14]. The reservoir contains large volumes of tailings that contain significant amount of copper and nickel minerals due to poor liberation or mechanical faults associated with mining operations. Therefore, a comprehensive reprocessing of these mine tailings to recover valuable metals by advanced mineral processing is very important to improve economic efficiency and lessen environmental destruction.

The main objective of this study was to assess an efficient approach for recovery of copper and nickel from the BCL Limited mine tailings of Botswana. For this purpose, influences of parameters in flotation and high pressure oxidative leaching processes on the recovery of copper and nickel from the mine tailings were discussed. Positive results of the research would help in ascertaining their feasibility for secondary resources.

\section{Experimental Section}

\subsection{Mine Tailing Composition and Analysis}

The mine tailings sample used in this study was taken from BCL Limited mine, Selebi Phikwe, Botswana. The mine tailing is represented as flotation tailings in the form of mud containing residual metal sulfides in the form of chalcopyrite, pyrite, pyrrhotite and pentlandite and reagents after flotation. The chemical content of the tailing sample was determined by coupled plasma-optical emission spectroscopy (ICP-OES, SPS 3000, Seiko instrument Inc., Japan) with a 5\% error, after the sample was digested using two acid digestion $\left(\mathrm{HCl}\right.$ and $\mathrm{HNO}_{3}$ ) procedure in order to dissolve most metals and mineral. Results showed that contents of copper and nickel were $0.19 \mathrm{wt} \%$ and $0.23 \mathrm{wt} \%$, while aluminum, magnesium, iron and silicon were $1.91 \mathrm{wt} \%, 1.32 \mathrm{wt} \%, 36.66 \mathrm{wt} \%$ and $37.37 \mathrm{wt} \%$ respectively (Table 1). Mineral composition of the tailing sample was determined using $X$-ray diffraction (XRD, Rigaku Co., Japan) and confirmed presence of pyrite $\left(\mathrm{FeS}_{2}\right)$, pyrrhotite $\left(\mathrm{Fe}_{(1-x)} \mathrm{S}\right)$ muscovite and quartz $\left(\mathrm{SiO}_{2}\right)$ as shown in Figure 1 . 
Table 1. Chemical composition of mine tailing.

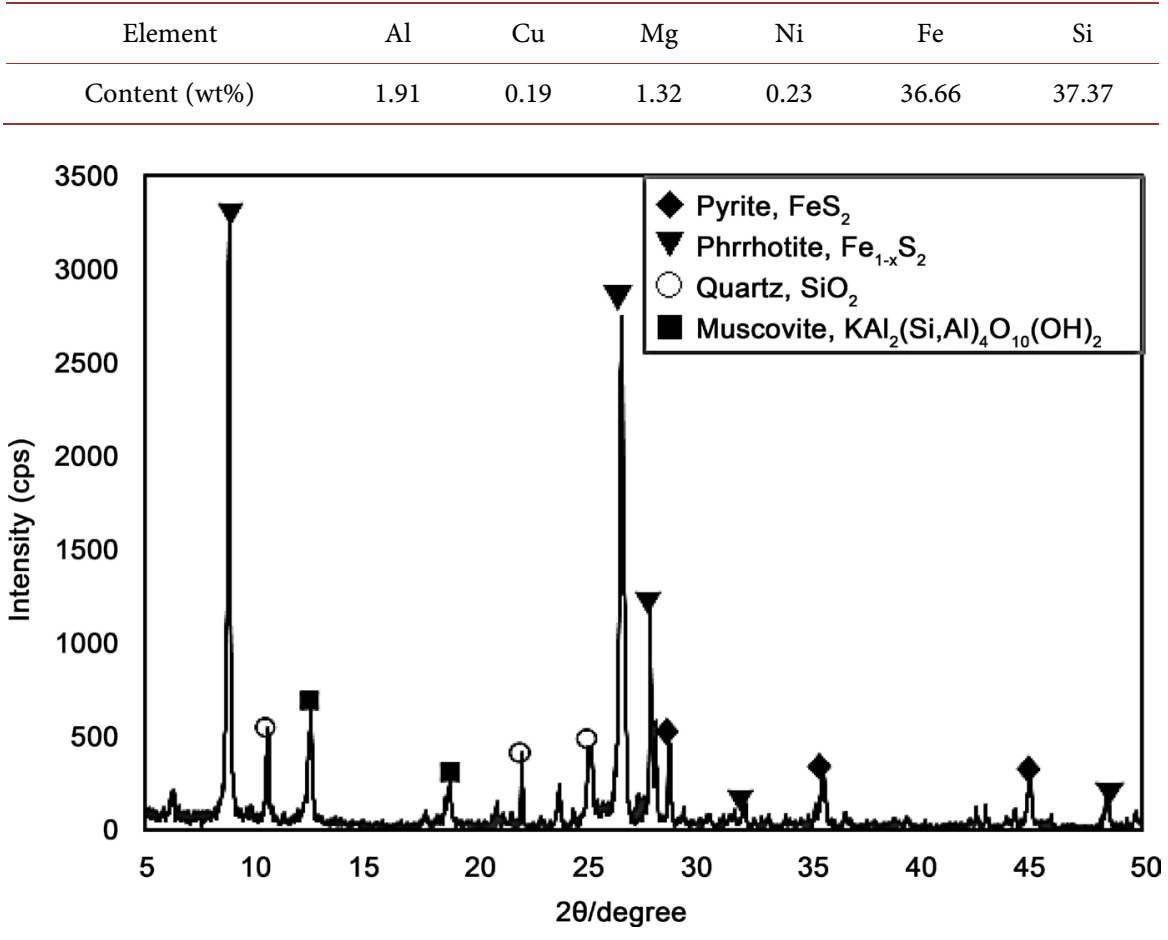

Figure 1. XRD pattern of mine tailing.

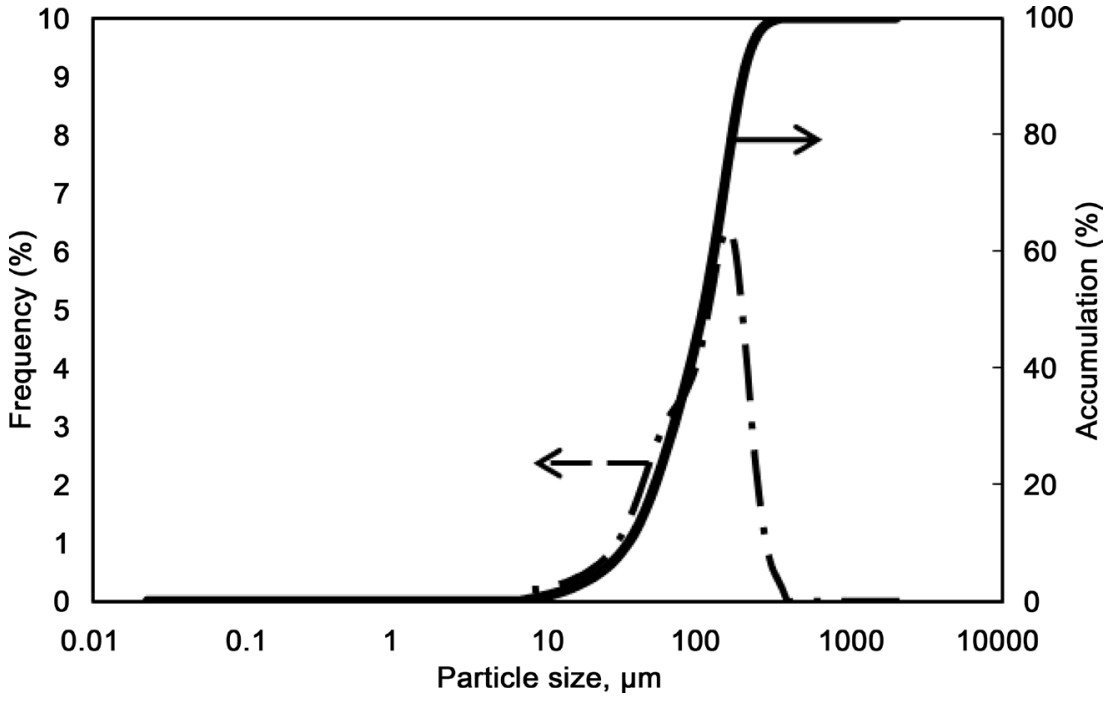

Figure 2. Particle size distribution of mine tailing.

The particle sizes of the tailing were from 35 to $100 \mu \mathrm{m}$ with the average particle size $\left(\mathrm{D}_{50}\right)$ of $70 \mu \mathrm{m}$ (Figure 2).

\subsection{Flotation Circuit}

The flotation experiments were performed in a $0.5 \mathrm{~L}$ mineral separator (MS) type laboratory flotation cell to upgrade recoveries of $\mathrm{Cu}$ and $\mathrm{Ni}$ (bulk flotation) from mine tailing. In flotation tests, an appropriate weight of the mine tailing sample was poured into $500 \mathrm{~mL}$ of water to prepare slurry/feed with different 
pulp densities from $10 \%$ to $25 \%$. Prior to flotation, desliming was carried out for 10 minutes to filter out floating clay minerals. At each experiment, conditioning was kept at 3 minutes after addition of reagents and flotation carried out for 6 minutes.

The reagents used were collector; Potassium amyl xanthate (PAX, $\mathrm{C}_{5} \mathrm{H}_{11} \mathrm{OCSSK}$ ), Mercaptan R247 (NaMBT, sodium 2-Mercaptobenzothiazole) and Aerofloat (AF208, sodium diethyl dithiophosphate); frother $200 \mathrm{~g} / \mathrm{t}$ of methyl isobutyl carbinol (MIBC, $\mathrm{C}_{6} \mathrm{H}_{14} \mathrm{O}$ ); sodium hydrosulfide (NaHS) as a sulfurizing agent, and calcium hydroxide $\left(\mathrm{Ca}(\mathrm{OH})_{2}\right)$ for $\mathrm{pH}$ adjustments. The collectors used in the experiments were supplied by Tokyo Chemical Industry, Japan. The flotation experiments were carried out at a stirring speed of $400 \mathrm{rpm}$ and air injected to promote bubble production as optimum parameters. In order to investigate the effect of other parameters such as pulp density, $\mathrm{pH}$, collector type and collector dosage, on the flotation efficiency, the stated parameters were varied individually within ranges. The concentrate and tailing were collected and dried in an oven for $6-8$ hours and determined the contents of copper and nickel by ICP-OES.

\subsection{High Pressure Leaching}

Leaching of froth concentrate obtained from flotation was studied in an autoclave system using sulfuric acid solution. Schematic diagram of an autoclave system used in the study is shown in Figure 3. To obtain optimal conditions for leaching conditions, experiments were performed in a $200 \mathrm{~mL}$ Teflon vessel placed into an autoclave under different sulfuric acid concentrations $(0-3 \mathrm{M})$, different temperatures $\left(100^{\circ} \mathrm{C}-180^{\circ} \mathrm{C}\right)$, different pressures $(1-2 \mathrm{MPa})$ and different contact times (30 - 150 minutes) at a fixed solid/liquid ration of 1/10 and stirring speed of $400 \mathrm{rpm}$. Namely, a vessel with slurry was placed into the autoclave and stirring speed and temperature were set up. When a certain target temperature stabilized, oxygen gas was supplied into the autoclave until the internal pressure reached a desired value and then leaching was conducted for the

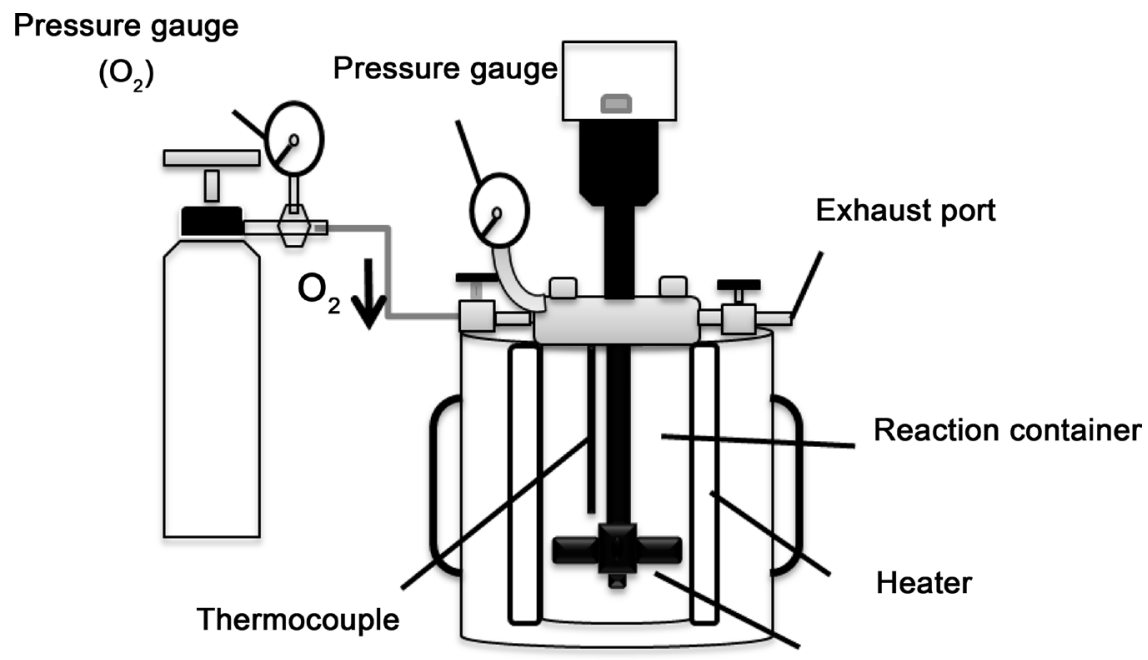

Stirrer

Figure 3. A schematic diagram of autoclave equipment used in the study. 
time adjusted. After the leaching process, the slurry was cooled down and filtered to obtain pregnant leached solution and solid residue. Leaching behavior of mine tailing sample and froth concentrate was compared under high pressure leaching using the determined conditions.

\section{Results and Discussion}

\subsection{Flotation}

\subsubsection{Effect of Different Collectors}

The effect of collector type on the recoveries of copper and nickel from mine tailing was studied using various collectors such as Potassium amyl xanthate (PAX, C5H11OCSSK), Mercaptan R247 (NaMBT, sodium 2-Mercaptobenzothiazole) and Aerofloat (AF208, sodium diethyl dithiophosphate). These collectors are widely used in sulphide minerals. In this study, flotation time was set at 6 minutes while collector and MIBC additions were fixed at $50 \mathrm{~g} / \mathrm{t}$ and $200 \mathrm{~g} / \mathrm{t}$ respectively. Natural $\mathrm{pH}$ of the slurry was 5 . The results for determining the effective reagent to use in the study are presented in Table 2. It can be seen that $\mathrm{Cu}$ and $\mathrm{Ni}$ grades were highest at $1.89 \mathrm{wt} \%$ and $0.61 \mathrm{wt} \%$ when NaMBT was added. The recoveries observed were $67.40 \%$ and $1.34 \%$ for $\mathrm{Cu}$ and Ni respectively therefore it shows no significant recovery to $\mathrm{Ni}$ due to poor floatability. Effect of PAX provided an overall effective bulk flotation as grades of $1.56 \mathrm{wt} \%$ and $0.75 \mathrm{wt} \%$, and recoveries of $84.73 \%$ and $25 \% \mathrm{Cu}$ and Ni were observed respectively. It has been observed that $\mathrm{Ni}$ recovery was substantially lower than copper recovery; this is particularly due to the presence of non-sulphide $\mathrm{Ni}$ in the ore and also lower floatability of pentlandite. Copper recoveries were favored in AF208 and Mercaptan R247 due to the shorter chain length of the collector's therefore increasing selectivity as discussed [15]. However, the mine tailings contained significant amount of sulphide minerals that associated with copper and nickel, PAX collector was suggested for further experiments due to its long chain and ability to promote the recoveries of copper and nickel which are associated with chalcopyrite, pyrrhotite and pentlandite.

\subsubsection{Effect of Collector Dosage}

Flotation behavior of copper and nickel from mine tailing was investigated under varying concentrations of PAX ranging from $0 \mathrm{~g} / \mathrm{t}$ to $200 \mathrm{~g} / \mathrm{t}$ when other flotation parameters were fixed at $200 \mathrm{~g} / \mathrm{t}$ of MIBC concentration, $50 \mathrm{~g} / \mathrm{t}$ of pulp density, slurry $\mathrm{pH}$ of $5400 \mathrm{rpm}$ of stirring speed and 6 minutes flotation time. As shown in Figure 4, an increase in PAX concentration lead to drastic increases in the grade and recovery of copper, whereas further increases in PAX had moderate changes in the grade and recovery of nickel. The grade and recovery of nickel increased up to $0.41 \mathrm{wt} \%$ and $31.0 \%$ from $0.17 \mathrm{wt} \%$ and $10 \%$ with increasing PAX dosage from 0 to $75 \mathrm{~g} / \mathrm{t}$. A further increase in PAX took place a gradual decrease in the grade and recovery of nickel. Results showed that the maximum recoveries of $\mathrm{Cu}$ and $\mathrm{Ni}$ were achieved at $87.80 \%$ and $29.77 \%$ when PAX dosage was $100 \mathrm{~g} / \mathrm{t}$ and $75 \mathrm{~g} / \mathrm{t}$, respectively. But a larger amount of collector would cause to float more iron sulfide minerals such as pyrite $\left(\mathrm{FeS}_{2}\right)$ and pyrrho- 
Table 2. Chemical composition of mine tailing.

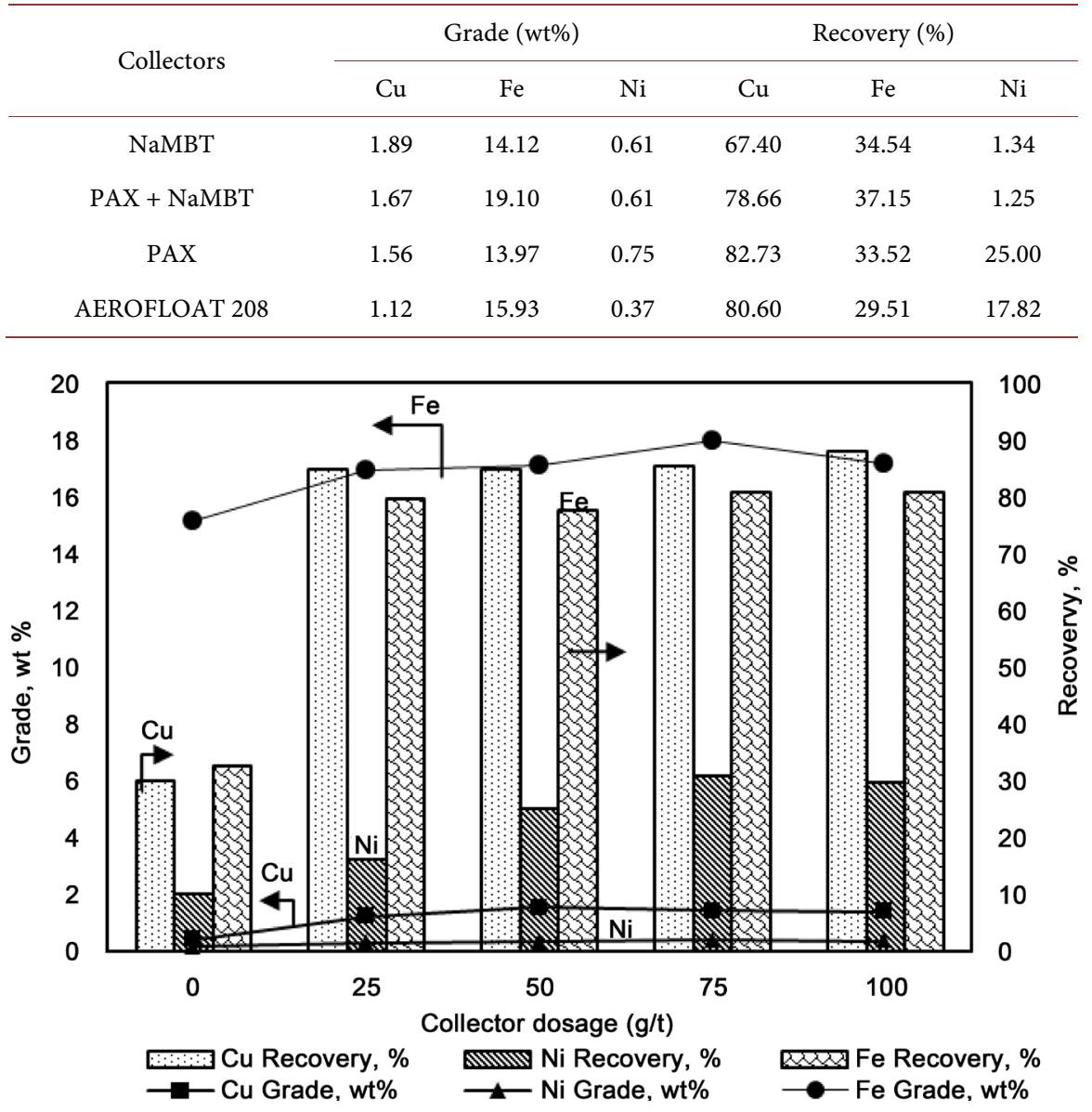

Figure 4. Flotation behavior of copper and nickel as a function of collector dosage (Flotation conditions: $10 \%$ pulp density, $\mathrm{pH}$, and flotation time of 10 minutes).

tite $\left(\mathrm{Fe}_{1-x} \mathrm{~S}\right)$ because the grade and recovery of iron increased with increasing of PAX dosage [15] [16] [17]. Therefore, PAX dosage was selected as $50 \mathrm{~g} / \mathrm{t}$ in further flotation studies.

\subsubsection{Effect of $\mathrm{pH}$}

To study the effect of $\mathrm{pH}$ on the flotation of mine tailing, $\mathrm{Ca}(\mathrm{OH})_{2}$ was used as a $\mathrm{pH}$ regulator through flotation experiments. The flotation tests were carried out at fixed conditions such as $50 \mathrm{~g} / \mathrm{t} \mathrm{PAX}, 200 \mathrm{~g} / \mathrm{t}$ MIBC, $50 \mathrm{~g} / \mathrm{t}$ pulp density for 6 minutes under different $\mathrm{pH}$ values ranging from 4 to 12 . It can be seen that both recovery and grade of metals $(\mathrm{Cu}, \mathrm{Ni}$ and $\mathrm{Fe})$ declined with increase in $\mathrm{pH}$. From Figure 5, it can be seen that $84.73 \%$ of copper and $30.89 \%$ of nickel were recovered as a flotation concentrate at $\mathrm{pH}$ 6. Consequently, $\mathrm{Cu}$ and $\mathrm{Ni}$ grade increased to $1.21 \mathrm{wt} \%$ and $0.99 \mathrm{wt} \%$ respectively. This observation could be attributed to the association of copper and nickel minerals with pyrrhotite and pyrite which are generally depressed in alkaline condition. On the other hand, under alkaline condition, iron sulfide minerals associated with copper and nickel could oxidized to form a layer of iron oxide or iron hydroxide resulting in an increase in the surface hydrophilicity of the mineral [17]. It was observed that the $\mathrm{pH}$ value 


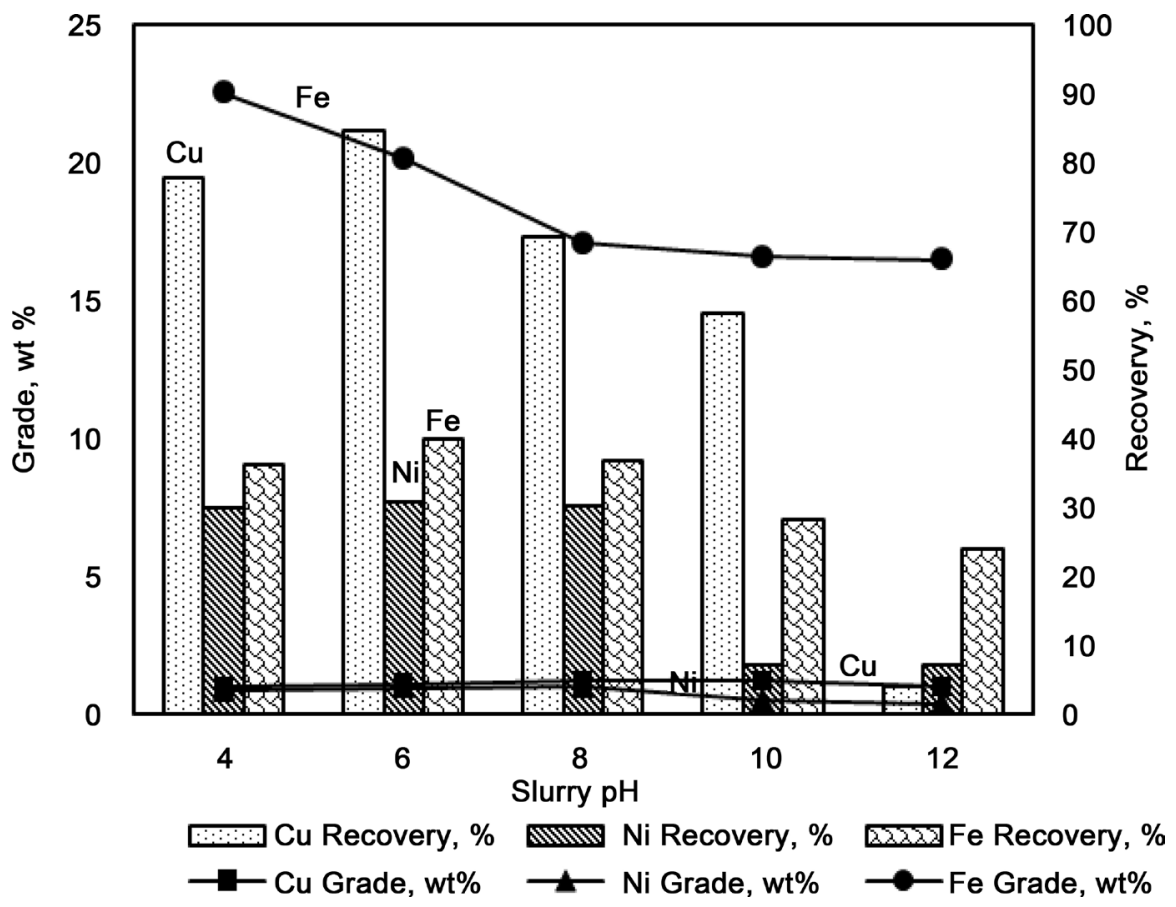

Figure 5. Effect of slurry $\mathrm{pH}$ on the recovery of copper and nickel. Flotation conditions: pulp density of $10 \%$, flotation time of $10 \mathrm{~min}$, PAX dosage (collector) of $50 \mathrm{~g} / \mathrm{t}$ and frother dosage of $200 \mathrm{~g} / \mathrm{t}$.

has shown to have a significant impact on the grade and recovery of copper and nickel from mine tailing. Therefore, a better approach to maintain reasonable recovery and grade is to keep at $\mathrm{pH} 6$.

\subsubsection{Effect of Pulp Density}

For recovery of copper and nickel from mine tailing, a number of flotation tests were carried out at fixed PAX dosage of $50 \mathrm{~g} / \mathrm{t}$, fixed MIBC dosage of $200 \mathrm{~g} / \mathrm{t}, \mathrm{pH}$ of 6 for 6 minutes when the pulp density was varied from $10 \%$ to $25 \%$. Experimental results were summarized in Figure 6. The results revealed that with increasing the pulp density from $10 \%$ to $25 \%$, recoveries of copper and nickel decreased up to $61.15 \%$ and $5.93 \%$ from $76.63 \%$ and $23.03 \%$, respectively. Figure 6 showed that the copper grade increased from $2.09 \%$ to $2.89 \%$, while Ni grade decreased from $0.95 \mathrm{wt} \%$ to $0.5 \mathrm{wt} \%$. The maximum recovery of $\mathrm{Cu}$ was $76.63 \%$ at pulp density of $10 \%$, but its grade was $2.09 \mathrm{wt} \%$.

\subsection{Optimized Conditions}

Optimum flotation conditions for recovery of the $\mathrm{Cu}$ and $\mathrm{Ni}$ from mine tailing were selected as $50 \mathrm{~g} / \mathrm{t}$ PAX, $200 \mathrm{~g} / \mathrm{t} \mathrm{MIBC,} \mathrm{10 \%} \mathrm{pulp} \mathrm{density} \mathrm{at} \mathrm{pH} 6$ for $6 \mathrm{mi}$ nutes. Under these conditions, the recoveries of $\mathrm{Cu}$ and $\mathrm{Ni}$ were $82.76 \%$ and $29.89 \%$, when grades of $\mathrm{Cu}$ and $\mathrm{Ni}$ were $2.09 \mathrm{wt} \%$ and $0.99 \mathrm{wt} \%$ respectively. Figure 7 showed the XRD patterns of the tailing sample and concentrate obtained from the flotation under the optimized conditions. It is evident that $\mathrm{Cu}$ bearing minerals gave a positive response to flotation while Ni-bearing minerals confirmed a more complicated floatability due to coexistence with gangue minerals such as 

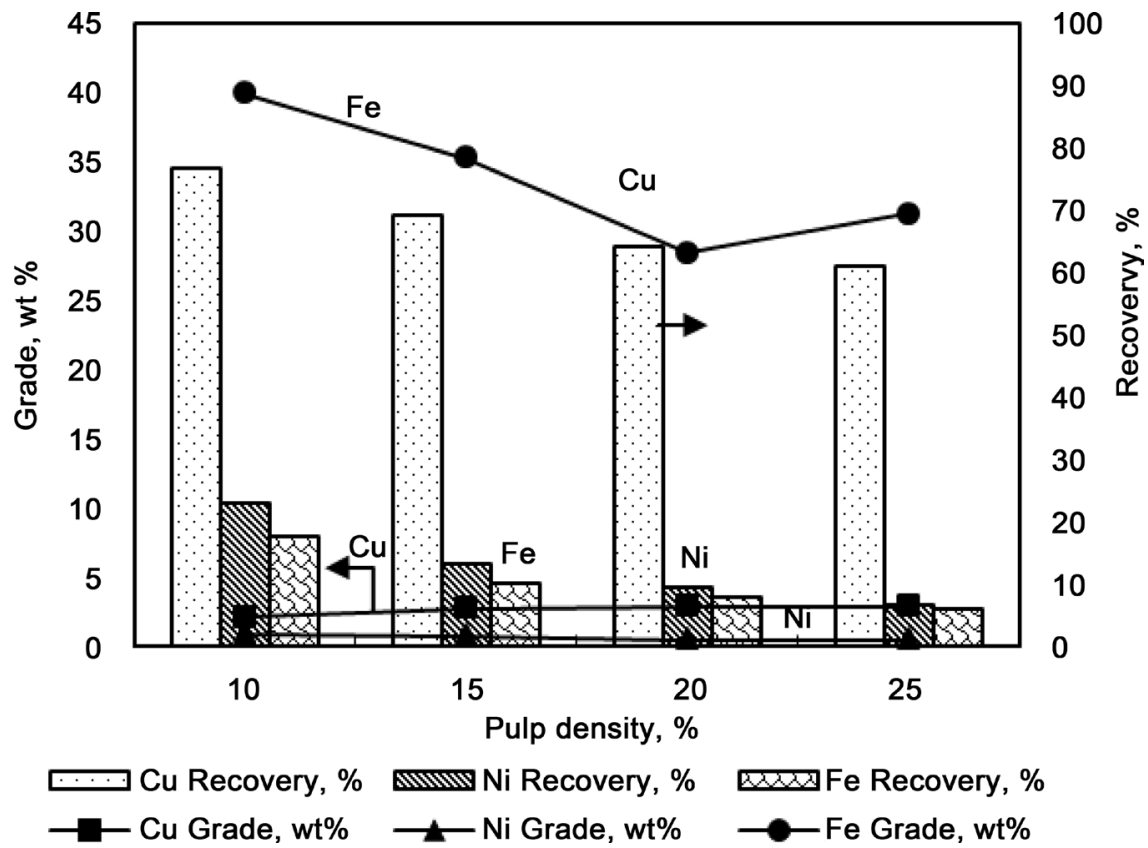

Figure 6. Effect of slurry $\mathrm{pH}$ on the recoveries of copper and nickel. Flotation conditions: pulp density of $10 \%$, flotation time of $10 \mathrm{~min}$, PAX dosage (collector) of $50 \mathrm{~g} / \mathrm{t}$ and frother dosage of $200 \mathrm{~g} / \mathrm{t}$.

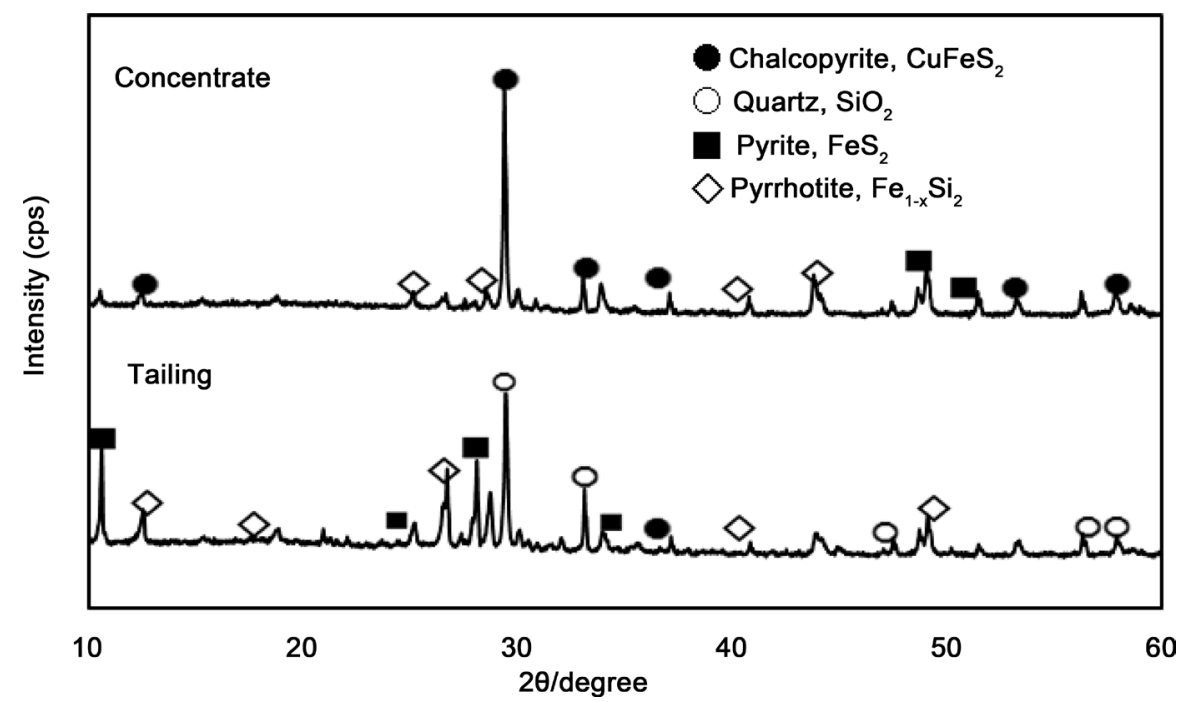

Figure 7. XRD patterns of the mine tailing sample and froth concentrate obtained from flotation under the optimum conditions determined (Pulp density: 10\%, collector (PAX) dosage: $50 \mathrm{~g} / \mathrm{t}$, frother (MIBC) dosage: $200 \mathrm{~g} / \mathrm{t}$, at $\mathrm{pH} 6$ for 6 minutes).

pyrite and pyrrhotite.

\subsection{High Pressure Leaching}

\subsubsection{Effect of Sulfuric Acid on the Dissolution of Copper and Nickel}

Dissolutions of copper and nickel from the froth concentrate and mine tailing were investigated under different sulfuric acid concentrations $(0-3 \mathrm{M})$, when other parameters like leaching temperature, stirring speed, solid/liquid phase ratio, total pressure and leaching are fixed at $140^{\circ} \mathrm{C}, 200 \mathrm{rpm}, 1: 10,1.5 \mathrm{MPa}$ and 30 
minutes. Sulfuric acid was chosen as a leaching agent because it is cheap and easily available.

As presented in Figure 8, under the experimental conditions, the leaching efficiencies of $\mathrm{Cu}$ and $\mathrm{Ni}$ from mine tailing gradually increased with increasing the concentration of $\mathrm{H}_{2} \mathrm{SO}_{4}$. Whereas a reverse trend observed in case of $\mathrm{Cu}$ and $\mathrm{Ni}$ leaching from the froth concentrate with increase in the $\mathrm{H}_{2} \mathrm{SO}_{4}$ concentration. When increase the $\mathrm{H}_{2} \mathrm{SO}_{4}$ concentration from $1 \mathrm{M}$ to $2 \mathrm{M}$, Cu leaching efficiency increased from $82.0 \%$ to $85.1 \%$, and then decreased up to $80.4 \%$ while the $\mathrm{H}_{2} \mathrm{SO}_{4}$ concentration further increase. The efficiency of nickel leaching from the froth concentrate decreased with increasing the $\mathrm{H}_{2} \mathrm{SO}_{4}$ concentration (Figure 8). It was observed that an increase of the $\mathrm{H}_{2} \mathrm{SO}_{4}$ concentration can enhance the $\mathrm{Fe}$ leaching efficiency from the both froth concentrate and mine tailing in the same trend. Under the leaching condition with $1 \mathrm{M} \mathrm{H}_{2} \mathrm{SO}_{4}$ leaching conditions as an optimum $\mathrm{H}_{2} \mathrm{SO}_{4}$ conditions, the efficiencies of $\mathrm{Co}$ and $\mathrm{Ni}$ leaching were $85.09 \%$ and $87.29 \%$ from the flotation concentrate, whereas $58.77 \%$ and $61.07 \%$ from the mine tailing sample. Results showed the nearly complete dissolution of copper and nickel from flotation concentrate compared to direct leaching of mine tailing under same leaching conditions.

As a result of the above experiments flotation concentrate was used for further leaching study.

\subsubsection{Effect of Temperature on the Dissolution of Copper and Nickel}

The effect of temperature on the dissolution of copper and nickel from the froth concentrate in an autoclave was studied under the stirring speed of $200 \mathrm{rpm}$ stirring, total pressure of $1.5 \mathrm{MPa}, \mathrm{H}_{2} \mathrm{SO}_{4}$ concentration of $1 \mathrm{M}$ for 30 minutes at different temperatures ranging from $100^{\circ} \mathrm{C}-180^{\circ} \mathrm{C}$. A closely monitored temperature is important for controlling products that are produced. The results

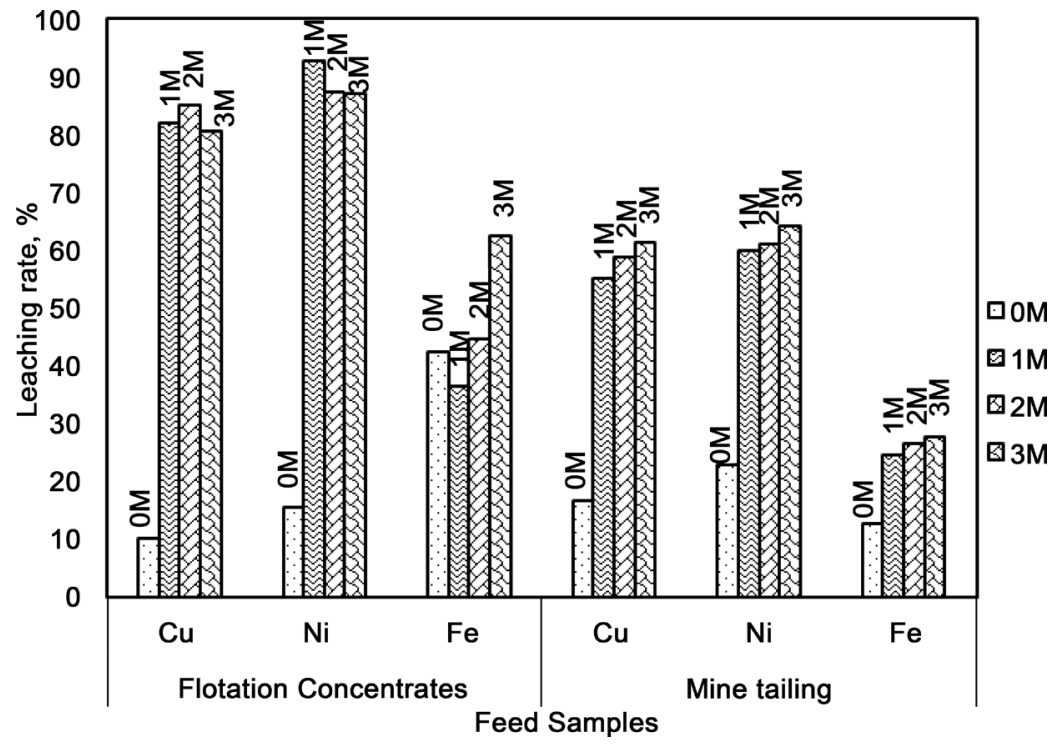

Figure 8. Dissolution of flotation concentrate and mine tailing with different concentrations of $\mathrm{H}_{2} \mathrm{SO}_{4}\left(\mathrm{H}_{2} \mathrm{SO}_{4}: 0-3 \mathrm{M}\right.$, total pressure $1.5 \mathrm{MPa}, \mathrm{S}: \mathrm{L}=1: 10$ at $400 \mathrm{rpm}, 140^{\circ} \mathrm{C}$ temperature for 30 minutes). 


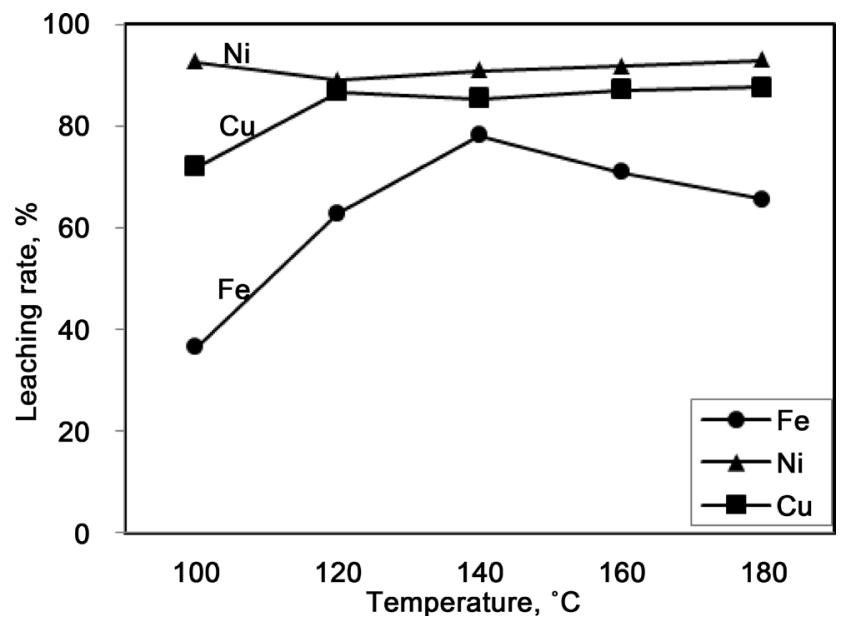

Figure 9. Dissolution of flotation concentrate as a function of temperature $\left(1 \mathrm{M} \mathrm{H}_{2} \mathrm{SO}_{4}\right.$, 1.5 $\mathrm{MPa}$ total pressure, $\mathrm{S}: \mathrm{L}=1: 10$ at $400 \mathrm{rpm}$ for $30 \mathrm{~min}$ ).

show that at a temperature of $140^{\circ} \mathrm{C}$ leaching rate reached to $98 \%$ and $96 \%$ for $\mathrm{Ni}$ and $\mathrm{Cu}$ respectively, Figure 9.

Dissolution of $\mathrm{Ni}, \mathrm{Cu}$ and $\mathrm{Fe}$ as a function of temperature can be made as indicated from preceding studies that have been reviewed. At an optimized temperature of $140^{\circ} \mathrm{C}$, complete dissolution of chalcopyrite, pentlandite, pyrite and pyrrhotite yield products of copper sulphate, nickel sulphate, ferric sulphate and ferrous sulphate. The dissolution of metals with $\mathrm{H}_{2} \mathrm{SO}_{4}$ solution under high pressure oxidative leaching conditions can be described according to the following Equations (1)-(3) [18]:

$$
\begin{gathered}
2 \mathrm{CuFeS}_{2}+5 \mathrm{H}_{2} \mathrm{SO}_{4}+2.5 \mathrm{O}_{2} \rightarrow 2 \mathrm{CuSO}_{4}+\mathrm{Fe}_{2}\left(\mathrm{SO}_{4}\right)_{3}+5 \mathrm{H}_{2} \mathrm{O}+4 \mathrm{~S}^{v} \\
2 \mathrm{FeS}_{2}+\mathrm{H}_{2} \mathrm{O}+11 / 2 \mathrm{O}_{2} \rightarrow 2 \mathrm{FeSO}_{4}+\mathrm{H}_{2} \mathrm{SO}_{4}+\mathrm{S}^{v} \\
\left(\mathrm{Ni}_{3} \mathrm{Fe}\right)_{9} \mathrm{~S}_{8}+3 \mathrm{H}_{2} \mathrm{SO}_{4}+31.5 \mathrm{O}_{2} \rightarrow 9 \mathrm{NiSO}_{4}+9 \mathrm{FeSO}_{4}+3 \mathrm{H}_{2} \mathrm{O}+\mathrm{S}^{v}
\end{gathered}
$$

The mechanism of hematite formation is explained as shown in below Equation (4):

$$
\mathrm{Fe}_{2}\left(\mathrm{SO}_{4}\right)_{3}+3 \mathrm{H}_{2} \mathrm{O} \rightarrow \mathrm{Fe}_{2} \mathrm{SO}_{3}+3 \mathrm{H}_{2} \mathrm{SO}_{4}
$$

\subsubsection{Effect of Pressure on the Dissolution of Copper and Nickel}

The influence of total pressure ( $P=P_{\text {vapor }}+P_{\mathrm{O}_{2}}$ ) on the leaching efficiencies of copper, nickel and iron in $1 \mathrm{M} \mathrm{H}_{2} \mathrm{SO}_{4}$ solution was investigated under various pressures from $1 \mathrm{MPa}$ to $2 \mathrm{MPa}$ at stirring speed of $200 \mathrm{rpm}$, solid/liquid phase ratio of $1: 10$, temperature of $140^{\circ} \mathrm{C}$ and leaching time of 30 minutes. Experimental results obtained are presented in Figure 10. The leaching efficiencies of $\mathrm{Cu}$ and $\mathrm{Ni}$ increase with increasing the pressure from $1 \mathrm{MPa}$ to $2 \mathrm{MPa}$, and become almost constant when the pressure increases further up to $3 \mathrm{MPa}$. When increasing the pressure, Fe leaching efficiency decreases drastically from 78.2 to $65.6 \%$. It is obvious that pressure leaching allows the simultaneous leaching of $\mathrm{Cu}, \mathrm{Ni}$ and $\mathrm{Fe}$ from the froth concentrate under the conditions. At $1.5 \mathrm{MPa}$ pressure, the maximum leaching efficiencies of $\mathrm{Cu}$ and $\mathrm{Ni}$ were achieved at 


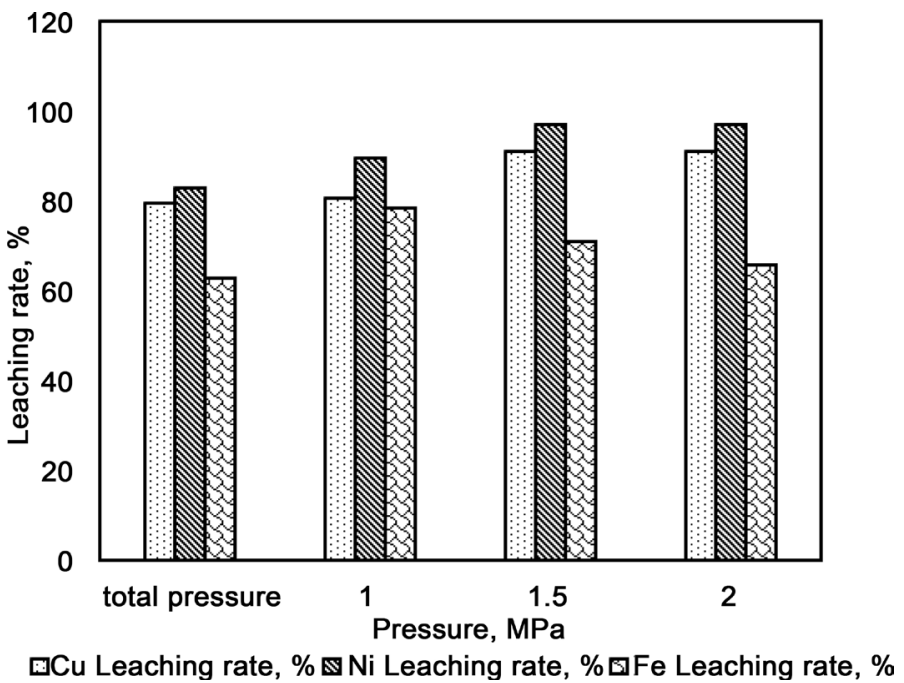

Figure 10. Dissolution of copper and nickel from flotation concentrate as a function of pressure $\left(1 \mathrm{M} \mathrm{H}_{2} \mathrm{SO}_{4}, 1.5 \mathrm{MPa}\right.$ total pressure, $\mathrm{S}: \mathrm{L}=1: 10$ at $400 \mathrm{rpm}, 140^{\circ} \mathrm{C}$ temperature for $30 \mathrm{~min})$.

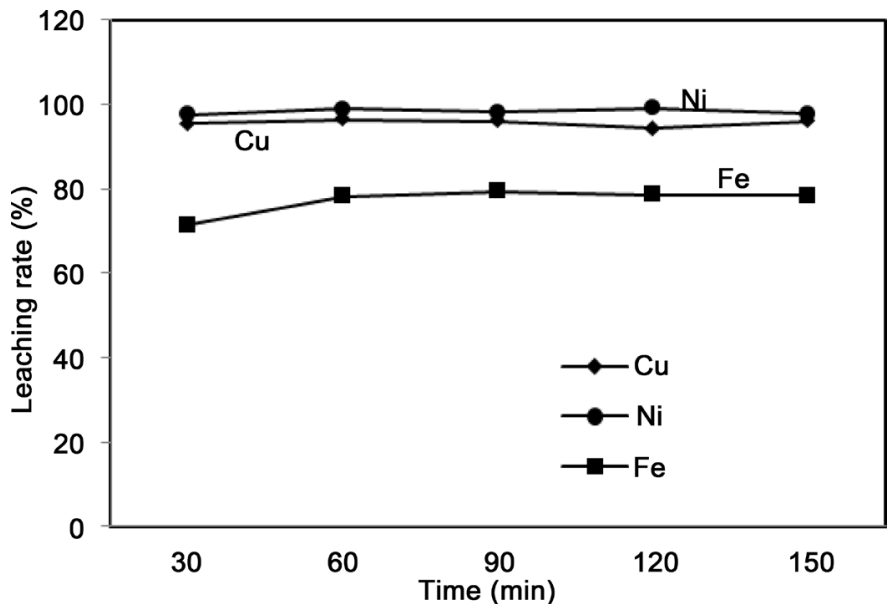

Figure 11. Dissolution of copper and nickel from flotation concentrate as a function of leaching time (30 - 150 min leaching, $1 \mathrm{M} \mathrm{H}_{2} \mathrm{SO}_{4}, \mathrm{~S}: \mathrm{L}=1: 10,1.5 \mathrm{MPa}$ pressure, $400 \mathrm{rpm}$ stirring speed at $\left.140^{\circ} \mathrm{C}\right)$.

$91.1 \%$ and $96.7 \%$, while the Fe leaching efficiency was $70.8 \%$. Therefore a 1.5 $\mathrm{MPa}$ pressure was chosen as an optimum pressure in the leaching process.

\subsubsection{Effect of Time on the Dissolution of Copper and Nickel}

The efficiencies of $\mathrm{Cu}, \mathrm{Ni}$ and Fe leaching were studied under the conditions determined previously as the pressure of $1.5 \mathrm{MPa}, \mathrm{H}_{2} \mathrm{SO}_{4}$ concentration of $1 \mathrm{M}$, solid/liquid phase ratio of $1: 10$, temperature of $140^{\circ} \mathrm{C}$, while the leaching time varied from $30 \mathrm{~min}$ to $150 \mathrm{~min}$. Results showed that the leaching time gave no obvious effect on the dissolution of copper and nickel from the concentrate under the conditions, because their leaching efficiencies were higher than $96 \%$ throughout the different time intervals (Figure 11). In the case of iron leaching, when leaching time increases from $30 \mathrm{~min}$ to $60 \mathrm{~min}$, Fe leaching efficiency increased from $71.3 \%$ to $78.2 \%$, but no further change was observed while the 


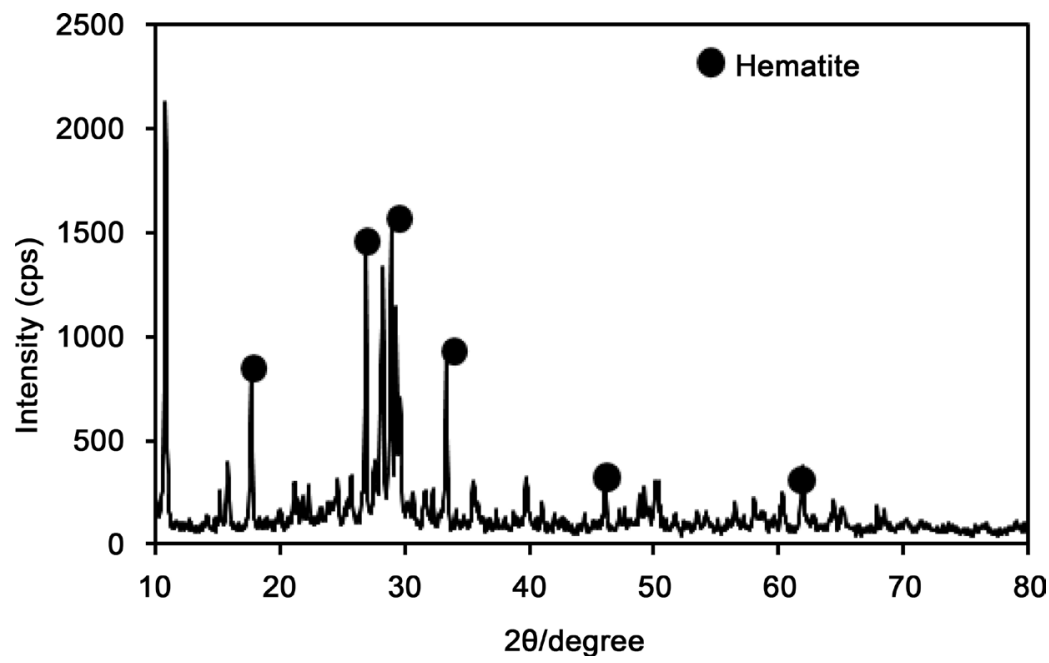

Figure 12. XRD patterns of the froth concentrate from flotation and solid residue from high pressure oxidative leaching.

leaching time increased until $150 \mathrm{~min}$. As a result, 30 minutes leaching was selected due to the higher dissolution of $\mathrm{Cu}$ and $\mathrm{Ni}$, and lower dissolution of $\mathrm{Fe}$ at the condition. Hence further leaching experiments would be carried out under the selected conditions as optimum leaching conditions. XRD measurement of the solid residue from the HPOL of the froth concentrate under the optimized conditions identified hematite as a main mineral constituent Figure 12. It is confirmed the formation of the hematite under the HPOL conditions according to Equation (4).

\subsection{Proposed Flowsheet for $\mathrm{Cu}$ and Ni Recovery from Mine Tail- ing}

Based on the above results, a general flowsheet for reprocessing of mine tailing can be proposed. The overall processes investigated in the current study are provided in Figure 13. Before flotation, desliming method was carried out for 30 minutes to allow gangue minerals that float to separate. In the case of flotation, nickel recovery was significantly restricted because of the finer particle size that occurred as solid inclusion with pyrrhotite. Other limiting factors to the upgrade and recovery of copper and nickel were the increased amount of floating gangue minerals. For the case of high pressure leaching, high dissolution values were achieved indicating the presence of readily leachable copper oxides, an observation that coincide with other researches [11].

\section{Conclusion}

In this study, recovery of copper and nickel from mine tailing was investigated by froth flotation and high pressure acid leaching processes. A maximum recovery of copper and nickel was reached at $84.73 \%$ and $30.9 \%$ while their grades were $2.09 \mathrm{wt} \%$ and $0.99 \mathrm{wt} \%$, respectively under the optimized flotation conditions: $50 \mathrm{~g} / \mathrm{t}$ PAX, $200 \mathrm{~g} / \mathrm{t} \mathrm{MIBC}$, slurry $\mathrm{pH}$ 6, flotation time for 6 minutes. Over $96 \%$ of copper and $98 \%$ of nickel were extracted from the froth/flotation con 


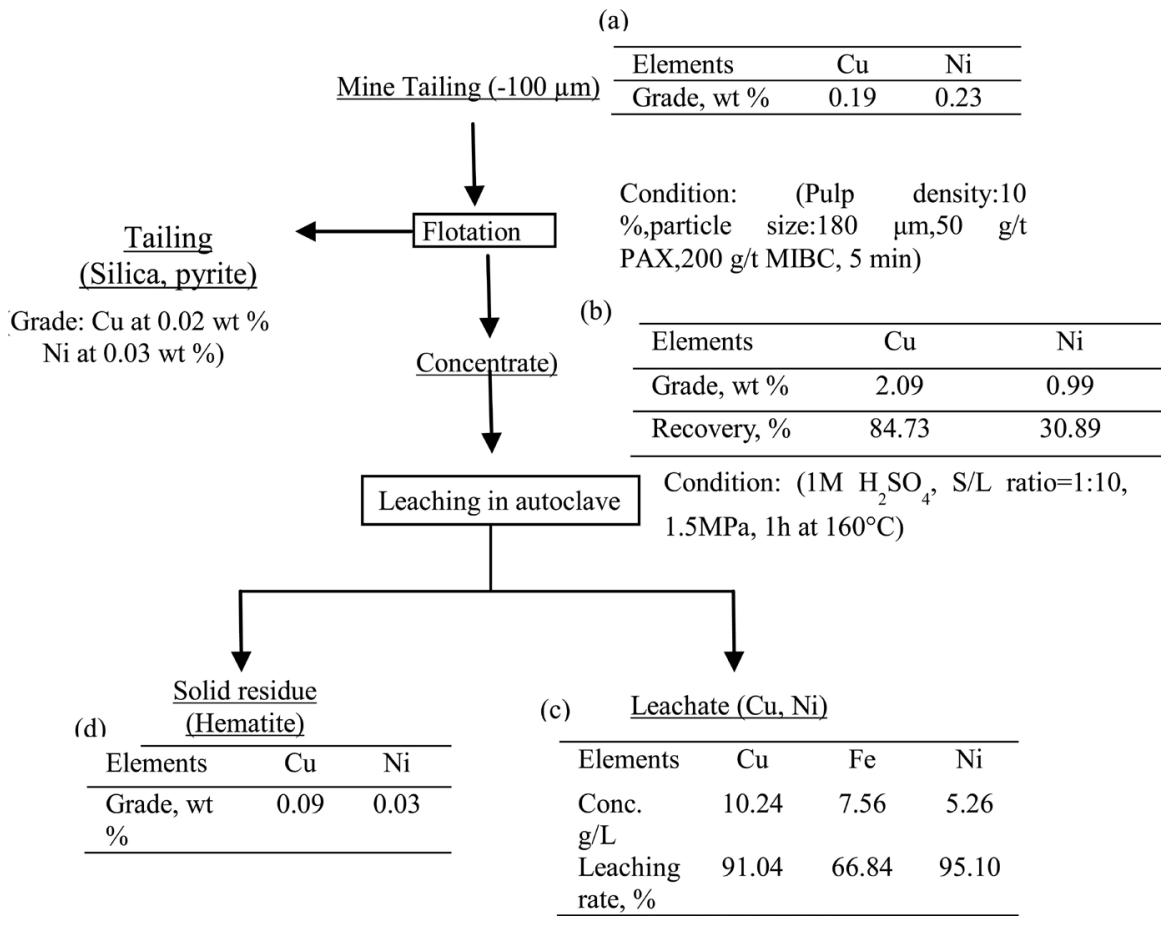

Figure 13. Schematic flowsheet for combined flotation and high pressure leaching for recovery of copper and nickel.

centrate, whereas about $55 \%$ of copper and $58 \%$ of nickel were dissolved from the mine tailing under the same leaching conditions. It can be concluded that the combined process of flotation and high pressure oxidative leaching (HPOL) is an efficient approach for recovery of copper and nickel from mine tailing. Throughout the flotation and HPOL processes, iron is simultaneously recovered from the mine tailing. It was revealed that the main iron minerals such as pyrite and pyrrhotite in mine tailing were converted to the hematite as results of the HPOL under the optimum conditions. According to this study, it is clear that other alternative methods such as magnetic separation need to be considered to increase nickel recover. The separation of iron bearing minerals from the final tailings is an important aspect to reduce possible acid mine drainage. As for the leachate solution, it is proposed that further separation method such as precipitation and electro winning need to be discussed.

\section{Acknowledgements}

This work was financially supported by JSPS Leading Program "New Frontier Leader Program for Rare-metals and Resources" in Akita University. We are grateful to the BCL Mine for providing us with the samples for performing this study.

\section{References}

[1] Karimi, H., Ghaedi, M., Shokrollahi, A., Rajabi, H.R., Soylak, M. and Karami, B. (2008) Development of a Selective and Sensitive Flotation Method for Determination of Trace Amounts of Cobalt, Nickel, Copper and Iron in Environmental Samples. Journal of Hazardous Materials, 151, 26-32. 
https://doi.org/10.1016/j.jhazmat.2007.05.051

[2] Senior, G.D. and Thomas, S.A. (2005) Development and Implementation of a New Flowsheet for the Flotation of Low Grade Nickel Ore. International Journal of Mineral Processing, 78, 49-61. https://doi.org/10.1016/j.minpro.2005.08.001

[3] Falagan, C., Grail, M. and Johnson, D.B. (2016) New Approaches for Extracting and Recovering Metals from Mine Tailings. Minerals Engineering, 106, 71-78.

[4] Evdokimov, S.I. and Evdokimov, V.S. (2014) Metal Recovery from Old Tailing. Journal of Mining Science, 50, 800-808. https://doi.org/10.1134/S1062739114040206

[5] Mudd, G.M., Weng, Z., Jowitt, S.M., Turnbull, I.D. and Graedel, T.E. (2013) Quantifying the Recoverable Resources of By-Product Metals: The Case of Cobalt. Ore Geology Reviews, 55, 87-98. https://doi.org/10.1016/j.oregeorev.2013.04.010

[6] Pan, H., Zhou, G., Cheng, Z., Yang, R., He, L., Zeng, D. and Sun, B. (2014) Advances in Geochemical Survey of Mine Tailing Projects in China. Journal of Geochemical Exploration, 139, 193-200. https://doi.org/10.1016/j.gexplo.2013.07.012

[7] Lutandula, M.S. and Maloba, B. (2013) Recovery of Cobalt and Copper through Reprocessing of Tailing from Flotation of Oxidized Ores. Journal of Environmental Chemical Engineering, 1, 1085-1090. https://doi.org/10.1016/j.jece.2013.08.025

[8] Xie, Y., Xu, Y., Yan, L. and Yang, R. (2005) Recovery of Nickel, Copper and Cobalt from Low-Grade Ni-Cu Sulfide Tailings. Hydrometallurgy, 80, 54-58. https://doi.org/10.1016/j.hydromet.2005.07.005

[9] Norgate, T. and Jahanshahi, S. (2010) Low Grade Ores-Smelt, Leach or Concentrate. Minerals Engineering, 23, 65-73. https://doi.org/10.1016/j.mineng.2009.10.002

[10] Huang, K., Li, Q. and Chen, J. (2007) Recovery of Copper, Nickel And Cobalt from Acidic Pressure Leaching Solutions of Low-Grade Sulfide Flotation Concentrates. Minerals Engineering, 20, 722-728. https://doi.org/10.1016/j.mineng.2007.01.011

[11] Antonijević, M.M., Dimitrijević, M.D., Stevanović, Z.O., Serbula, S.M. and Stevanović, G.D. (2008) Investigation of the Possibility of Copper Recovery from the Flotation Tailings by Acid Leaching. Journal of Hazardous Materials, 158, 2334. https://doi.org/10.1016/j.jhazmat.2008.01.063

[12] Quast, K., Connor, J.N., Skinner, W., Robinson, D.J., Li, J. and Addai-Mensah, J. (2015) Preconcentration Strategies in the Processing of Nickel Laterite Ores Part 2: Laboratory Experiments. Minerals Engineering, 79, 269-278. https://doi.org/10.1016/j.mineng.2015.03.016

[13] Garg, S., Papangelakis, V., Edwards, E. and Mahadevan, R. (2017) Application of a Selective Dissolution Protocol to Quantify the Terminal Dissolution Extents of Pyrrhotite and Pentlandite from Pyrrhotite Tailings. International Journal of Mineral Processing, 158, 27-34. https://doi.org/10.1016/j.minpro.2016.11.004

[14] Simwaka, M., Gumbie, M., Moswate, P., Keitshokile, D.C. and Dzinomwa, G. (2009) Milestones in the Improvement of Concentrator Nickel And Copper Recoveries at BCL. Proceedings Base Metals Conference the Southern African Institute of Mining and Metallurgy, Kasane, 27-31 July 2009, 359-582.

[15] Bag, B., Das, B. and Mishra, B.K. (2011) Geometrical Optimization of Xanthate Collectors with Copper Ions and Their Response to Flotation. Minerals Engineering, 24, 760-765. https://doi.org/10.1016/j.mineng.2011.01.006

[16] Bulatovic, S.M. (2007) Handbook of Flotation Reagents. Elsevier Ltd., Amsterdam.

[17] Haga, K., Tongamp, W. and Shibayama, A. (2012) Investigation of Flotation Parameters for Copper Recovery from Enargite and Chalcopyrite Mixed Ore. Materials Transactions, 53, 707-715. https://doi.org/10.2320/matertrans.M2011354

[18] Free, M.L. (2013) Hydrometallurgy: Fundamentals and Application. John Wiley \& Sons, Inc., Hoboken. https://doi.org/10.1002/9781118732465 
Submit or recommend next manuscript to SCIRP and we will provide best service for you:

Accepting pre-submission inquiries through Email, Facebook, LinkedIn, Twitter, etc. A wide selection of journals (inclusive of 9 subjects, more than 200 journals)

Providing 24-hour high-quality service

User-friendly online submission system

Fair and swift peer-review system

Efficient typesetting and proofreading procedure

Display of the result of downloads and visits, as well as the number of cited articles Maximum dissemination of your research work

Submit your manuscript at: http://papersubmission.scirp.org/

Or contact jmmce@scirp.org 